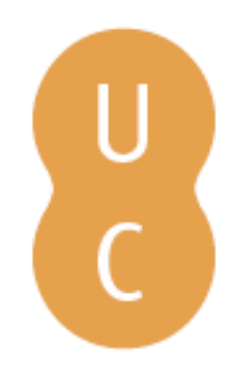

\title{
pommalina
}

\section{Place concepts as poetic interruptions}

\author{
Autor(es): $\quad$ BenPorat, Ziva \\ Publicado por: Imprensa da Universidade de Coimbra \\ URL \\ persistente: URI:http://hdl.handle.net/10316.2/42326 \\ DOI: $\quad$ DOI:https://doi.org./10.14195/978-989-26-1308-6_16
}

Accessed : $\quad$ 26-Apr-2023 13:51:46

A navegação consulta e descarregamento dos títulos inseridos nas Bibliotecas Digitais UC Digitalis, UC Pombalina e UC Impactum, pressupõem a aceitação plena e sem reservas dos Termos e Condições de Uso destas Bibliotecas Digitais, disponíveis em https://digitalis.uc.pt/pt-pt/termos.

Conforme exposto nos referidos Termos e Condições de Uso, o descarregamento de títulos de acesso restrito requer uma licença válida de autorização devendo o utilizador aceder ao(s) documento(s) a partir de um endereço de IP da instituição detentora da supramencionada licença.

Ao utilizador é apenas permitido o descarregamento para uso pessoal, pelo que o emprego do(s) título(s) descarregado(s) para outro fim, designadamente comercial, carece de autorização do respetivo autor ou editor da obra.

Na medida em que todas as obras da UC Digitalis se encontram protegidas pelo Código do Direito de Autor e Direitos Conexos e demais legislação aplicável, toda a cópia, parcial ou total, deste documento, nos casos em que é legalmente admitida, deverá conter ou fazer-se acompanhar por este aviso.

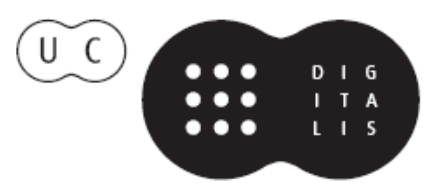





\section{PLACE CONCEPTSAS POETIC INTERRUPTIONS}

Ziva Ben-Porat

Resumo: O artigo aplica a redefinição de Maria Irene Ramalho Santos do conceito de "interrupção poética" de Fernando Pessoa, ou seja, a interferência do político/cultural na representação de uma visão poética, ao estudo do conceito de lugar e do próprio lugar. Transponho a sua ligação entre a "interrupção poética" e os usos da linguagem para a ativação cognitiva de conceitos linguísticos, eventualmente exteriores à visão original do poema, e demonstro o funcionamento do processo a partir da análise de várias traduções, explicações e interpretações de um poema modernista hebraico. Mostro também em que medida uma imagem que se destina a evocar um determinado estado de espírito e não a representar uma entidade geográfica precisa pode ser interpretada, sob o impacto cognitivo de tal interferência, como uma representação "mimética".

Palavras-chave: Interrupção poética; conceitos e representações do lugar; representação mimética; poesia modernista hebraica. 


\begin{abstract}
In this paper I apply Ramalho Santos's re-definition of Pessoa's "poetic interruption" as the interference of the political/cultural in the representation of a poetic vision to a study of place concepts and real places. I translate her linking of "poetic interruption" with use of language to cognitive activation of linguistic concepts that might be external to a poem's original vision, and demonstrate such processes by analyzing a number of translations, explications and interpretations of a modernist Hebrew poem. I show how an image designed to evoke moods rather than represent a "real" geographical entity might be interpreted, under the cognitive impact of such interference, as a "mimetic" representation.
\end{abstract}

Keywords: Poetic interruption; concepts and representations of place; mimetic representation; modernist Hebrew poetry.

To MIR, an esteemed colleague and beloved friend

In the seventh chapter of her book Atlantic Poets Irene Ramalho Santos presents "Poetic Interruption," which she defines as the interference of our culturally constructed world - hence "the political" - not only as a "Pessoan concept for reading the lyre" (222) but also as the generative force behind the poetical:

By bringing the political to break in upon the poet's unifying imagination, interruption is actually what accounts for the poetical. . . the political facts of life go on interrupting the poet's vision, thus allowing for its actual poeming. In this sense of the political, ... politics calls attention to the limits of language that 
necessarily render the freedom of poetry writing problematic, thus inviting the self-conscious, artful use of language that amounts to poetic fiction. (Idem)

I translate this aspect of "poetic interruption" to cognitive activation of linguistic concepts that might be external to a poem's original vision, by either writer or readers. By doing this I try to reunite Pessoa's claim with that of Ramalho Santos', consciously and sometimes intentionally misreading them both. Whereas they initially speak of a real interruption in the process of writing or reading a poem, I refer to associations triggered by linguistic usages. Whereas Ramalho Santos speaks about the liberation of culturally fettered reality by the free poetic imagination which it infiltrates, I emphasize the fetters by which language limits the freedom of imagination. By this I refer to the well-known fact that language uses us as much as we use it. I claim that an unplanned and uncontrolled activation of any cultural concept often mars - or at least contaminates the clarity of a poem's underlying poetic vision on the one hand and interrupts the reading of such texts on the other. An image designed to evoke moods rather than represent a "real" entity might be interpreted, under the cognitive impact of such interference, as a "mimetic" representation.

I shall illustrate my claims through a study of a well-known modernist Hebrew poem by Nathan Alterman (the most influential Hebrew-Israeli poet of the second third of the $20^{\text {th }}$ century), two of its translations and three conflicting interpretations (academic articles and papers/exams of High-School students). The two place concepts associated with the reading of Alterman's poem, my claimed poetic interruptions, are those of Jerusalem and Paris. However, the motivations for their activations are very different and exemplify the variety of potential triggers. With respect to Jerusalem it is easy to see and show in the text the net of attributes that comprise the 
concept "Jerusalem" in Hebrew culture. Paris, on the other hand, is triggered by features of Modernist - Beaudelairian in particular - poetry and biographical facts concerning the poet's stay there shortly before writing this poem.

Alterman, whose poem "Summer Night" (1934) is then the focus of this article, is generally accepted as one of the leading Israeli Modernist poets and at the same time is described and analyzed as a French Symbolist. English and American, as well as German Modernist poetry, arrived late in Israel. Although such period and poetic school identifications should act as a warning against attempts to look for mimetic representations, Paris and Jerusalem can and have been evoked, revoked or subdued by readers of the same text. Moreover, academic interpreters and translators tended to adapt an either-or policy rather than embrace the complexity of two conflicting (re)constructions of potential background or underlying localities. The mixed triggering attributes not only invoke two distinct representations but can change the cultural associations which constitute the cities' auras. More accurately, the modern city of French symbolism can be manipulated to challenge the historically dominant conceptualization of Jerusalem as "the eternal holy [ruined] capital of Israel."

In a number of studies and experiments, conducted during the last 25 years, I found out that this cultural concept of Jerusalem, already established in the Bible, but emerging as a poetic model of writing (and hence reading) in the Middle Ages, is still the dominant concept even in the minds of Israelis who have first-hand familiarity with the city. The concept has not changed in Israeli Hebrew speaking society in spite of the incredible political, social and economic changes that took place throughout the $20^{\text {th }}$ century. The major attributes of the concept are still: the Wailing Wall, broken walls, stones, holiness, domes, spires and longings. Only pine trees and clear air have been added to the top of the 
list since 1967, when Naomi Shemer composed her "Jerusalem of Gold"1.

In more than 800 questionnaires (200 hundred in 2013), in which participants have been asked to list and then grade the cultural salience of the city's attributes, the old city, The Temple Mount or Moslem and Christian Holy Places lag behind the ancient traditional attributes cemented after Jerusalem's Fall in Roman times. So do all the important landmarks and institutions of the contemporary city (such as the Knesset [Parliament], the Hebrew University, the High Court of Justice or even the Teddy Football Arena). Consequently, every text - verbal or visual - presenting ruined walls, rocks, domes and spires, without any landmark or verbal instruction to contradict the traditional identification, activates the cultural concept "Jerusalem." Such activation effects the composition but does not necessarily lead to close or similar readings of the poem in which they appear. Poetic interruption can work in various directions.

Bracketing individual personality traits and contextual factors, different interpretations can result from different conceptual nets related to active cultural memory. Place concepts represent such memory structures embodied in the language. In the following discussion I show how the early introduction of a phrase which relates a great length of time with Jewish history in general, and the destruction of Jerusalem in particular, effects the poet's use of language and imagery to the point of leading his innocent readers (and sometimes even literary scholars) away from his poetic vision. The vision, reconstructed on the basis of the poem's dominant characteristics, calls for an emotive - rather than logical, historical or narratological - integration of the poem's distinct and unrelated images, but the activation of a place concept pulls in the direction of concretized imagery.

1 See, for example, Ben-Porat 1988, 1991. 


\section{ליל קיץ}

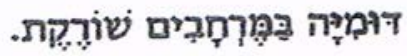

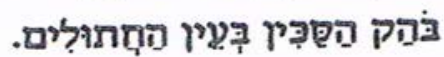

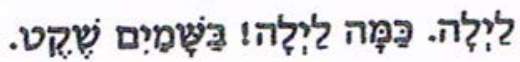

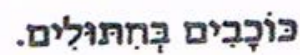

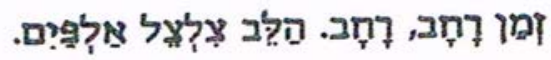

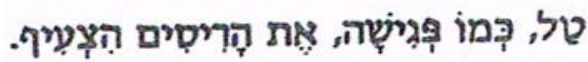

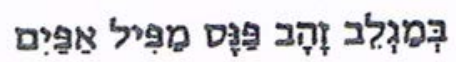

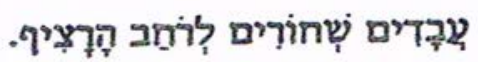

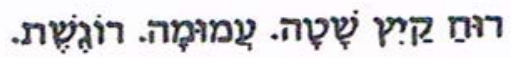
רע

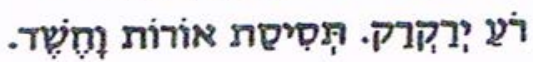

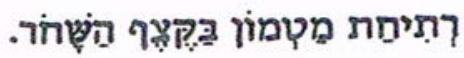

$$
\begin{aligned}
& \text { עורד }
\end{aligned}
$$

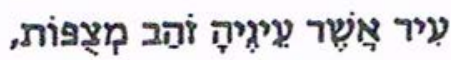

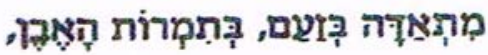

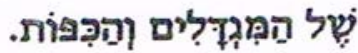

Literal translation by B. Hrushovsky (1965)

Silence whistles in the (wide) spaces.

Glitter of a knife in the eye of cats.

Night. How much night! In the skies: quiet.

Stars in swaddling clothes. 
A wide wide time. The heart rang two thousand.

Dew, like an encounter, veiled the lashes.

With a golden whip a street-lantern throws down (prostrates)

Black slaves across the width of the platform.

A summer wind roams (floats). Muted. Agitated.

Her (the wind's) lips are poured out upon shoulders of gardens.

Greenish malice. Fermentation of lights and suspicion.

Boiling of a treasure in the black foam.

And far, toward the height, with famished growl,

A city whose eyes are plated with gold,

Evaporates in rage, in the stone billows

Of the towers and the copulas.

This literal translation is part of a project entitled "The Hebrew Poem Itself." ${ }^{2}$ The wish to present the non-Hebrew reader with the "poem itself" explains some of the features of this translation. Hrushovsky refrains from any attempt to fit the text into English syntactic patterns, to introduce any explanatory element to the string of distinct images, or to hide moments of indecision (embodied in options presented in parentheses), and contrariwise allows himself even to explain a reference ("her [the wind's]" 1.10). The solution to the unavoidable loss of Alterman's prosodic genius is the inclusion of an English transliteration of the Hebrew text. The underlying justification of this complex behavior is undoubtedly grounded

2 The project, initiated and edited by Stanley Burnshaw, resulted in a very successful book by that name, featuring many editions. In the most recent one (2003) only the author's name is changed: Harshav replaces Hrushovsky. For that reason I include both in the list of citations. Because the time line is relevant to my argument I keep referring to the name used in the first edition (namely, Hrushovsky). 
in Hrushovsky's wish to avoid as much as possible the inevitable interpretive nature of all translations.

Translations are always interpretations in disguise. They are never presented as such because changes are justified by formal or linguistic constraints, but it is quite easy to reconstruct a translator's interpretation following her decisions or their justifications. Aiming to unveil interpretive decisions with respect to poetic interruptions, I begin with a comparison of two translations. Please note that only Friend's poetic translation (positioned on the left half of the page) is reproduced in full. Hrushovsky's is printed above. In order to juxtapose the two as clearly as possible (namely, on the same page) identical translated segments appear only once on the left of the page and are represented by hyphens (- -) on the right side, the one which contains the literal translation.

\section{Nathan Alterman, "Summer's Night"}

(Poetic translation by Robert Friend, 1978) （Literal translation by B. Hrushovsky, 1965)

Silence whistles in the open spaces.

A knife in a cat's eye glows.

Night! How much night! In the sky, stillness. - - -

Stars in swaddling clothes.
Silence whistles in the (wide) spaces.

Glitter of a knife in the eye of cats.

In the skies: quiet.

A wide, wide time. The heart's clock rang two thousand. - - The heart rang - -

Dew, like a rendez-vous, veiled the lashes.

- - like an encounter - -

A street lamp hurls black slaves across the pavement

As its gold whip flashes.

With a golden whip a street-lantern

Throws down (prostrates)

Black slaves across the width of the platform. 
A summer wind wanders, dim and agitated,

Lips tonguing the shoulders of the gardens.

A greenish evil. Suspicion, lights -fermenting.

A treasure seething under the froth of darkness.

- - roams (floats). Muted. Agitated.

Her (the wind's) lips are poured out upon shoulders of gardens.

Greenish malice. Fermentation of light and suspicion

Boiling of a treasure in the black foam.

And high on the mountain, with a famished roaring, And far, toward the height, With famished growl,

Its eyes a golden fire, a city whose eyes are plated with gold, Wrathfully a city vaporizes evaporates in rage, in the stone billows

Amidst stone pillars, and soaring dome and spire. Of the towers and the cupolas.

The bold indicates elements belonging to the dominant representation of Jerusalem; the underlining indicates translation decisions that support the activation of the traditional conceptualization. Explicit mention of the traditional attributes exists in the original text - most likely the result of the initial poetic interruption. Therefore, their presence does not indicate particular interpretive decisions on the part of the translators. But the choice of one translation option out of several provides such indication. From this perspective both translations suggest a mild attempt to tone down the water related and the erotic potential Paris triggers. But both retain them when they can be useful in diminishing the effects of the Jerusalem concept.

The most striking example of this tendency is Hrushovsky's hesitation about the translation of the verb in the description of the wind's movement in line 9. He puts "floats," the closest equivalent to the Hebrew [sh-a-ta] in parentheses, while opting for "roams". Both Friend's "wander" and Hrushovsky's "roam" are adequate translations, but they weaken the potential activation of 
the water related Paris concept. This, as I claimed, reveals the underlying force of the poetic interruption, the activated Jerusalem concept. Nonetheless, Hrushovsky enhances Alterman's ambiguous metaphorical formulations when he translates the upward movement of the stone (1.15) as "billows."

These translation decisions may then be explained either by the unconscious activation of the cognitive concept Jerusalem in the minds of the translators or by a deliberate attempt to enhance such activation, perceiving it as a feature of Alterman's poetic vision. However, it is clear that both translators realize and cherish the modernistic qualities of the poem and maintain them. Neither would read it as a poem about Jerusalem, Paris, or any other "real" place.

Although the poem has not been particularly popular with literary critics, it has been used by teachers of literature. As a result there are numerous readings available: some - mostly those of literary critics - perceive and accentuate a French connection, conspicuous, for example, in Friend's "rendez-vous" (1. 6). Even if the French term attracted Friend by the possibility of rhyming it with dew, activation of a Paris concept might have generated it. Other interpreters foreground Jerusalem. Still other, like Hrushovsky (particularly as an explicator and interpreter), insist on the a-localization of the images.

In his early explication of the poem, (1965), in the context of the forementioned Introduction to Modern Hebrew Poetry, Hrushovsky writes:

A mysterious atmosphere surrounds the speaker who waits as if lost in time and space. No other people, no specific events, yet something is happening around him in the warm summer night. The setting of the poem spreads out between two fields of light: the innocent stars far above in the quite sky (stanza 1) and 
the fuming stones of a distant city evaporating in the rage of its illuminated towers and cupolas (stanza 4). Dimensions of time and of space overlap. The lone speaker feels that time is motionless and almost unreal. It is a matter of "How much night!" and of "wide wide time" - [using inappropriate adjectives in both cases results in abstraction and unrealistic effect]. (107)

If a link to the historical Jerusalem concept comes to a reader's mind, Hrushovsky's detailed insistence on the abstract unrealistic effect of the poem undercuts such linkage. The thrust towards abstraction is strongly evident already in Hrushovsky's explication of the second line.

Line 2 is a typical Alterman device: creating abstract qualities by manipulating concrete elements. The cats - a traditional accessory in magical circumstances - are not individualized; they are endowed with one collective menacing eye. The "glitter of the knife" - later echoed by "greenish evil" - is at once contrasted with the "quietude" of the skies. [stanza 1]. (Ibidem)

Hrushovsky's presentation of the poem combines explication and interpretation. This combination generates a complex organization of the argument. A line-by-line reading (explication) mingles with the construction of comprehensive de-localized frames (interpretation), resulting in repetitions. For example, in his treatment of 1.5 (presented below), the repeated illustration of the mingling of the temporal and the spatial is practically unconnected to the ensuing analysis of the rest of 1. 5. It is nevertheless functional in his effort to foreground the abstract nature of Alterman's imagery.

Time is not old but wide. Only the heart marks the passage of time by its fateful ringing. The number 2000 , which refers to 
the span of the diaspora, is an extremely hackneyed phrase in Israel, a proverbial expression for interminable duration. Hence, for the heart, the length of time seems unreal, immeasurable. [emphasis mine]. (Ibidem)

This is probably the point at which Alterman's struggle with the "poetic interruption", induced by an established linguistic practice, begins. And so is Hrushovsky's. Unable to ignore the reference's triggering power, since the years of the diaspora cannot be separated from the remembrance of and longing for Jerusalem, Hrushovsky puts it down as too "hackneyed" to activate - or even be included - in the concept of Jerusalem. He presents it as just a reference to a very long time. The reason for such a strong action becomes clearer as the explication of the poem continues.

The sudden encounter (6), answering as it were the heart's expectancy (5), is introduced by an inverted simile - thus it is not explicitly embedded in the setting [or in a potential plot/story]. The erotic element $[5,10]$ is not individualized but becomes an element in a setting suffused with unreal imagery. (ibidem)

No "heart's expectancy" is mentioned in the poem. It cannot but be perceived as the offspring of the Jerusalem concept activation the poetic interruption Hrushovsky as reader (and maybe Alterman as writer) is struggling with. The longing of the Jews in the diaspora to return to Zion - an option triggered by the "heart rang two thousand" could be fictionally related to a happy coming together which brings tears ("dew") to the eyes of the participants. Such fictionalization and grounding in reality are strongly negated as interpretive options in Hrushovsky's previous explicatory segment. He must now make special efforts to eliminate it. This he does by focusing on the inverted simile, which makes "dew" rather than the 
"encounter" the subject of the phrase. It could be argued that the inversion emphasizes the reviving force of the encounter with Zion and its God or that dew is typical of warm nights in the desert. But what is important for my argument is Hrushovsky's elaborate effort to eliminate these options.

Hrushovsky shows that the effect of timelessness, created by the image of immeasurable time

is emphasized by the predicateless sentences $(2-5,11-12)$ and the preponderance of nouns (almost 5 times as many as verbs and adjectives). Though the sensuous elements are present, they are generally divorced from their normal environments. Thus each introduces a realm of its own, rich with overtones, but the resulting images are vague in outline, emphasizes the diffused haziness of this summer night and the feeling of something vague, strange, ominous. (idem: 108)

The main insights that this explication provides, in accordance with Hrushovsky's literal translation, with respect to our interest in Jerusalem/Paris as cognitive models potentially interfering in and affecting the interpretation of the poem, are the following:

1) Hrushovsky reads the text as a symbolist poem in which the main element is an abstraction - an idea of alienation and anxiety coupled with fascination, enchantment and desire; the emotional effect and the music of the text are more important than logical inferences, literal significations and reconstructed coherent representations of reality.

2) If a Paris mental construct is involved in the processing of the text, it is a concept of Paris embodied in a specific variant of symbolism. 
3) Hrushovsky's awareness of the potential activation of a Jerusalem concept reveals itself in his effort to minimize the potential triggering force of Jewish elements (detailed above).

4) This a-localization characterizes his translation, which is much more faithful (than Friend's) to the original text. Hrushovsky keeps the original water-related words (floats, 1. 9 and billows, 1. 15) although he uses "platform" where "quay" might have been a better choice. And yet, his "platform" might work better than Friend's "pavement" if the aim is to rule out any activation of "Jerusalem."

Equipped with knowledge of Alterman's stay in France and the time of composition (the second half of the 1930s after a long stay in France) and with his established association with French symbolism, other scholars read into the amorphous description a representation of an actual - if fictionalized and romanticized - Paris. In a book sub-titled Alterman's Poetry from a modernist Perspective (1989) ${ }^{3}$, Ziva Shamir, for example, claims that

The surrealist bewitched description is nothing but a unique and uncommon way for describing a real and ordinary city late at night, when the windows that have been lit up by yellow electrical light grow dark and the buildings get covered by a dark black fog, as if disappearing in billows of hazy mists; or, just the opposite, a description of a city in the early morning hours, when windows lit up slowly by the sunshine's golden light until it wakes up [with zest and appetite] ("a famished growl") to face a new day in life.

3 I use my own translation of the sub-title in order to foreground what I called "the French connection". The Hebrew title is a quotation from one of Alterman's best known poems, and the official translation of the title, The Vagrant Bard: Avant-Garde and Alterman's Poetic Style is, to my mind, less revealing. 
If we take off the city's mythical veil we end up with a banal routine picture of a city. $(75)^{4}$

"The ominous effect of the glittering knife in the eye of a cat" is interpreted by Shamir as

the sense of danger experienced by a person when walking in the abandoned outskirts of the city subjected to the criminal underworld. The glitter of the knife can be associated with a real knife in the hands of a criminal or with the straightforward fact of the elongated and narrow pupil of a cat's eye. (78)

Although Shamir does not explicitly claim that the real city of the poem is indeed Paris, she suggests it by referring to the quays as the sites of commerce and loading activities by day and attractive hookers by night. She substantiates the implied identification of the city as Paris by a number of references to the poetry of Baudelaire and by quoting a possible source of direct influence - a poem by Leon Valade, a minor symbolist poet of the second half of the $19^{\text {th }} \mathrm{c}$., entitled "Nuit de Paris." This poem, according to Shamir, shares with Alterman's the

mixture of poetic romanticism and daily life; an arbitrary mixture of evil and tenderness, of spirituality and materialism. . . Both poems upgrade a picture of banal city daily life to the level of magical witchcraft through the use of techniques of "making strange" and mystification; and both mention the summer's night gilded eyes (stars - explicitly mentioned in Valade's poem and lit-up windows inferred from Alterman's description). (81)

\footnotetext{
${ }^{4}$ All quotations from Shamir's book are in my unauthorized translation.
} 
Sensitive to dualities in the imagery and in the constructed argument of the poem, Shamir claims that the conflicting triggers typify the Modern broken and divided image, "in which opposites maintain their strong opposition and do not merge" (74). The opposites in her reading are the alternative options of looking at the poem either as representing a city disappearing as the dark night takes over or, conversely, a city waking up (75). She concludes by unveiling the modernist function of such dualities: "If we take off from the picture its mythical heavenly veil a banal and ordinary picture of a city emerges" (idem).

The marked effect of the Paris concept as the key to this reading is evident not only in the explicit grounding of Shamir's interpretation in the symbolist tradition and her constant references to Parisian attributes (such as the Seine), but also in her treatment of contrasting or interruptive elements. She too has to marginalize and dispel the effects of the strong "Jerusalem" triggers. So she presents "the heart rang two thousand" as a verse "spoken sentimentally, sweetly and gently, like the sentimental poetry of the chansonniers" (idem). She explicates the stone billows of the last stanza as the spreading darkness or as morning fogs - "both are only means towards mystification of a routine city-scape at night-fall or day-break" (idem). Naturally, under the spell of a specific poetic interruption, she ignores the triggering potential of "domes and spires" or other "Jerusalem" attributes.

In contra-distinction to the scholarly activation of a literary conceptualization of Paris on the basis of the stylistic qualities of the text, without any triggers such as the characteristic landmarks or attributes of the city's conceptualization and with blatant disregard for potential triggers of the concept Jerusalem, almost all "innocent" Israeli readers (mostly high-school students struggling with an unseen passage) read "Summer's Night" as a poem about Jerusalem. Unspecified references to towers and domes, in conjunction with 
stone, gold, and 2000 years, sufficed to activate the representation "Jerusalem" in their minds. This supports my claim that even people who were born in Israel and know the modern Jerusalem very well from first hand experiences carry in their heads an image that was planted there by cultural memory. From the Biblical descriptions of the glorious capital and of Jerusalem in ruins, through the Medieval poetry of longing and remembrance, followed by many poems, piyuttim (traditional religious poetry) and prayers, and culminating in many popular songs, this list of attributes, paradoxically concrete abstractions (e.g. domes and not the Golden Dome), came to dominate a concept of a city which is a locus of national identity, and consequently whose past can almost completely overshadow its present.

While the identification of Jerusalem as a possible object of the poem's description was a common denominator in the work of many students, few exhibited an ability to work with the concept in order to achieve a more comprehensive and cohesive interpretation (beyond attributing every other element in the poem to a surrealistic modern fictional place). Those who did achieved comprehensive and consistent interpretation on the basis of the activated concept and its historical aura. Their arguments can be summarized in the following way: If the city is Jerusalem, the speaker is not inside the city, but is quite far away, in real open spaces (and not objective correlatives). Some even said5: the speaker is in the Judea Desert which recalls the early history of the Hebrews. The prostrated beaten slaves could then be related to our history in Egypt. The whip acquires a literal signification alongside its metaphorical usage in the description of the street-light at night. Evil's association with water is explained by the Nile and the early Hebrew life on its banks. The wrath with

\footnotetext{
5 Please note that this is not a quotation of a particular paper but a collage of statements made orally by students who claimed the poem to be about Jerusalem.
} 
which Jerusalem wakes up is in such interpretations recounted as a history of rebellion and fight for freedom.

Evidently such interpretations move even farther away from Alterman's a-localization than Shamir's Symbolist Paris. Nevertheless, all exemplify the strong effect of the poetic interruption caused by the activation of a place concept. At the same time, they exemplify the poeticizing effect of a poetic interruption: whole imaginary worlds are constructed as a result of the interference which, as Ramalho Santos formulated it, "necessitates the artful use of language that enables/allows the creation of poetic fiction."

\section{Works cited}

Alterman, Nathan [see Hebrew list - the 2 items in Hebrew at the end of the bibliography below].

Ben-Porat, Ziva. "History in Representations of Jerusalem" Neobelicon XIV/2 (1988): 353-358. Print.

—. "Two Way Pragmatics: From World to Text and Back." Ed. R. Sell. Literary Pragmatics. London: Routledge, 1991, 142-163. Print.

Burnshaw, Stanely, et al. The Modern Hebrew Poem Itself. New York: Holt, Reinhart \& Winston, 1965. Print.

- The Modern Hebrew Poem Itself. Wayne State University Press, 2003. Print. Hrushovsky, Benjamin. "Alterman's summer Night." The Modern Hebrew Poem Itself, 1965, 111-113. Print.

Ramalho Santos, Irene. Atlantic Poets: Fernando Pessoa's Turn in Anglo American Modernism. Hanover and London: University Press of New England, 2003. Print.

Shamir, Ziva. 1989 [see Hebrew list- the 2 items in Hebrew at the end of the bibliography below].

אלתרמן, נתן. 1938. כוכבים בחוץ. תל-אביב: הוצאת יחדיו.

שמיר, זיוה.1989. עוד חוזר

הניגון: שירת אלתרמן בראי המודרניזם. תל-אביב: פפירוס בית ההוצאה באוניברסיטת תל-אביב 